- 86- 九州菡会詀・第 25 卷第 I号 (1971)

\title{
X線頭部規格写真を応用した，唇・顎・口蓋裂患者の上顎測定法
}

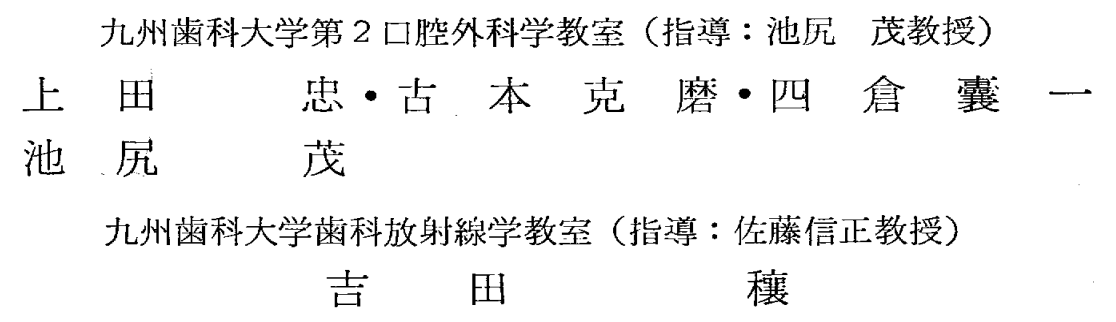

（昭和46年 4 月 I 日受理）

\section{A METHOD OF MEASURING THE MAXILLA OF CLEFT LIP AND PALATE PATIENTS BY USE OF THE ROENTGENCEPHALOMETRY}

By

Tadashi UEDA, Katsuma KOMOTO, Johichi YOTSUKURA and Shigeru IKEJIRI Second Department of Oral Surgery (Director: Prof. Shigeru IKEJIRI) Yutaka YOSHIDA Department of Dental Radiology (Director: Prof. Nobumasa SATO) Kyushu Dental College, Kitakyushu, Japan

We are using onlay-transplantation of iliac bone crest on the hypoplasia maxilla base to elevate the affected ala base of the nose to the level of the other side.

We use roentgencephalometry to determine criteria for transplantation of bone.

We report the measurements and the results of the maxilla, with cleft lip and palate, on the roentgencephalometry.

The measurements were made as follows.

We applied contrast medium on the facial middle line and outerside of each ala nasi.

We measured the distance ketween the ear rod and alae nasi, left and right, of 9 patients with cleft lip and palate and of 23 normal adults.

The results are as follows.

The measurements for 23 normal adults were of course in the normal range. Those for 8 patients out of 9 were in the normal range, but those for the remaining one were in abnormal range.

Onlay-transplantation of iliac bone crest was performed for the abnormal case and a desired result was acheived.

はじめに

口唇裂患者は，しばしば，顎裂および口盖裂をともな い, それにより，鼻翼，鼻孔の側方拡大，鼻翼基底部， 鼻孔底部の陥凹，それにともなう鼻翼の変形，鼻軟骨の 変位, 変形などがみられる。

兔唇鼻翼形成法については，諸家の記載がみられる
が，その鼻翼形態の回復は，必ずしも容易ではない。

現在, 私達の教室に扔いては, 唇・䫁・蓋裂患者の 鼻翼に変形がみられ，それが上顎骨基底部の発育不全を 之もなうと思和机る症例に対して, 鼻翼形態回復の一助

として，鼻翼基底部に骨移植を行なっている。

すなわち，患側鼻翼付着部が健側に較べて，矢状面に 
てどの程度の差があるかを，数值的に計測するために， 側方頭部 X線規格写真撮影法を応用し, 顔面㳄組織のプ ロフィルを作り，乙れを，移植骨片の厚さの決定に利用 している，その側方頭部 X線規格写真撮影法による測定 法，および，本法を応用して骨移植を行なった1例につ いて報告し，諸賢の御批判を仰ぎたい。

装置执よび測定方法：

装置は九州歯科大学, 霜科放射線学教室の頭部 $\mathrm{X}$ 線規 格撮影装置を使用した。

この撮影装置は，X線管球よりフィルム面までの距離 が $240 \mathrm{~cm}$ ，顔面正中部が，フィルム面より $12 \mathrm{~cm}$ になる ように調節されている. 撮影に先立ち, 軟組織側貌を得 るために, 顔面正中部, 左右の鼻翼付着部に, 造影剂で 線を画いた (図1参照).

図1

\section{頭部侧方X缘规格写真摄影等道}

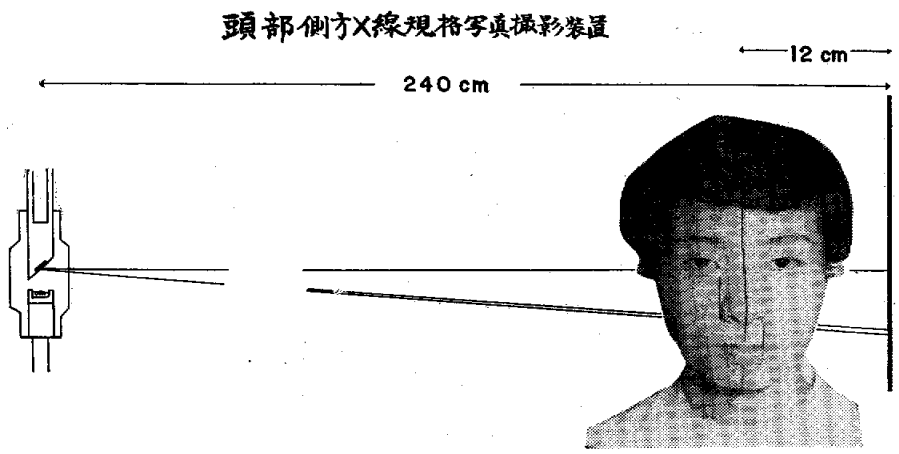

測定方法は，耳の固定装置の中心部より，左右の鼻翼 付着部までの距離を, フィルム上で測定し，その左右差 とこ机らの测定值より換 算して実長差を得た（図 2 参 照).

図 2
赛長の算定には，次のような計算を行ない，図４の表 を作製し使用した。

計算方法：

$\mathrm{X}$ 線管球よりフィルム面までの距離 : $240 \mathrm{~cm}$, 正中部 より, 左右マークまでの距離（左右鼻翼付着部）を $a$ と すると，右打よび左は，12+ $a ， 12-a$ の数式にて現わ される. フィルム上で, 耳固定装置中心部より左右マ一 クまでの距離を $\mathrm{F}$ とする。

実長Xを算出するには，

右側の場合は,

$240: \mathrm{F}=\{240-(12+a)\}: \mathrm{X}$

$$
\mathrm{X}=\frac{\mathrm{F}\{240-(12+a)\}}{240}
$$

左側の場合は，

$$
\mathrm{X}=\frac{\mathrm{F}\{240-(12-a)\}}{240}
$$

の数式にて算出される.

$a$ （正中より左右鼻翼付着部までの距離）が $2 \mathrm{~cm}$ $4 \mathrm{~cm}$ の範囲に㧊いては, 左右ともに, 実長に換算する さい，その差は，I $\mathrm{mm}$ 以内で，臨床上，問題にならな い，それと，実際に，正中部より，左右舅翼付着部まで 测定した值が， $3 \mathrm{~cm}$ 前後が最も頻度が高く， $\quad a=3 \mathrm{~cm}$ で計算し図 4 の表を作製した (図3，4参照).

図 3

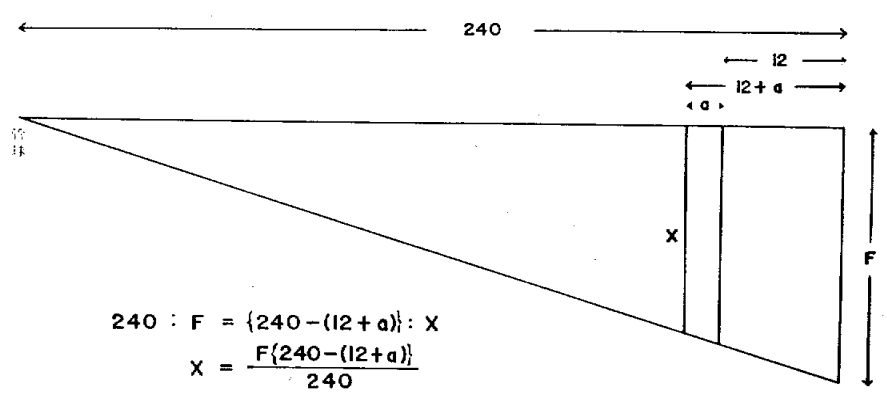

使用造影剂抢よび軟組織に造影剂を塗布する方法：

造影剂としては，硫酸バリウム，モルヨドールを使用 し，モルヨドールにて硫酸バリウムを練和した。

軟組織に塗布する方法としては，ラバー印象剂注入器 を使用し，接着をよくするために，女性化粧用パックを 事前に塗布して, 造影剤の接着を助長した。

\section{測定成績 :}

辰・顎・蓋裂のない，正常と思われる成人23例之， 唇・顎・蓋裂患者 9 例の合計32例について測定した。 結果は，図５に示すようになる，その测定値の左右值 差，すな⿰力口，X線フィルム上での左右投影值差扔上び 奉長差は， ○〜3 mmの範囲にあり，また，唇・顎・ロ 


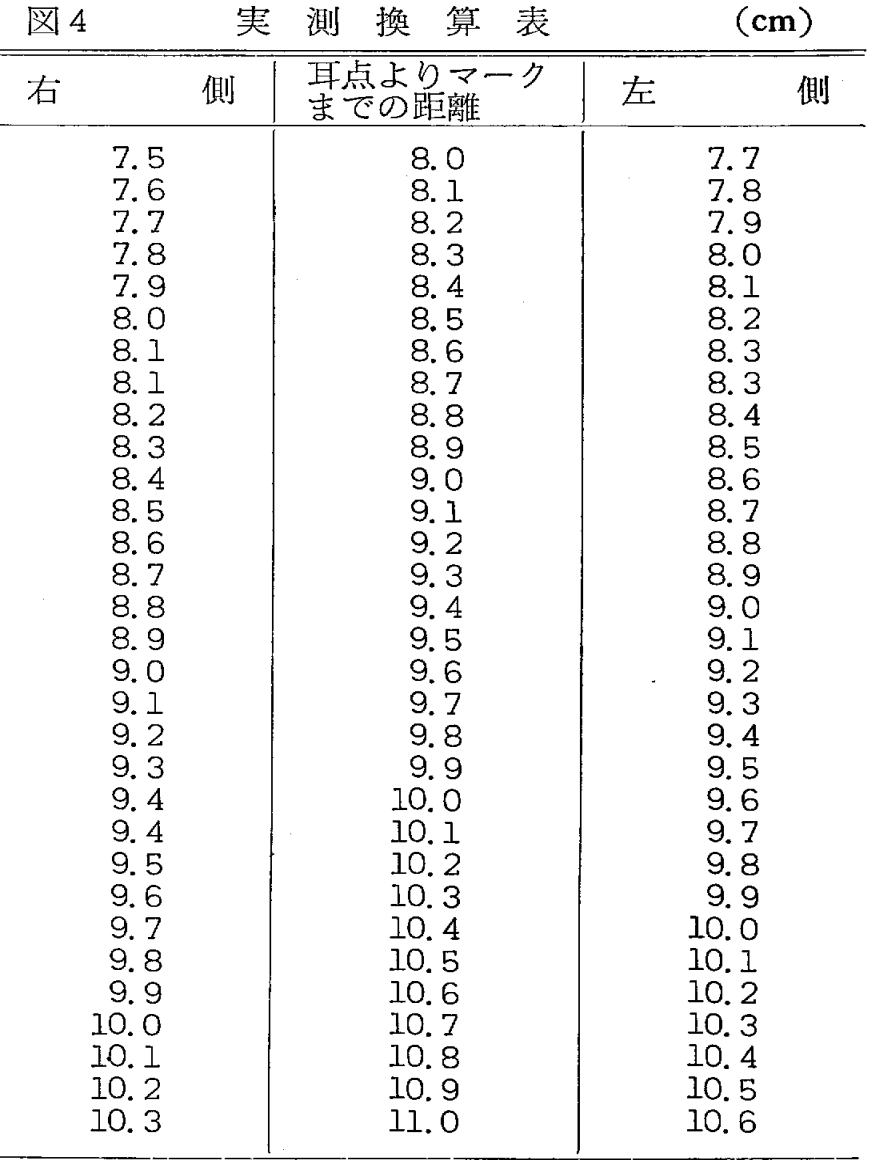

家族，既応歴：と屯に特記すべき事項はみあたらない 現病歴：3才ごろ, 唇・顎・口蓋裂の形成手術を受 け，昭和45年 4 月に，再度，顎裂の形成手術を受けてい る.しかし，鼻翼の非対称性を主訴として，その形成を 希望し来院した。

全身所見：体格，栄養状態亡あに良好，貣血傾向ある いは，特別な異常所見はみあたらなかった。

局所所見 :

口腔外所見；唇裂形成の手術創痕がみられ，左側鼻翼 が，圧平された状態が観察されるととあに，左側鼻翼付 着部の後退が認められる.

口腔内所見；顎口蓋裂形成の手 術創痕が みられ，ま た，㕮合を行なうと，明らかに下顎前突の状態を示して いた.

臨床検查成績; 血液, 尿ともに異常を認めなかった。 側方頭部 X線規格写真による観察：

前述の方法にて撮影し測定換算した結果，左右投影值 差 $6 \mathrm{~mm}$, 実長差 $4 \mathrm{~mm}$ で, 左侧鼻翼基底 部の後退を明 示することができた（図6，7，8参照).

\section{図 6}

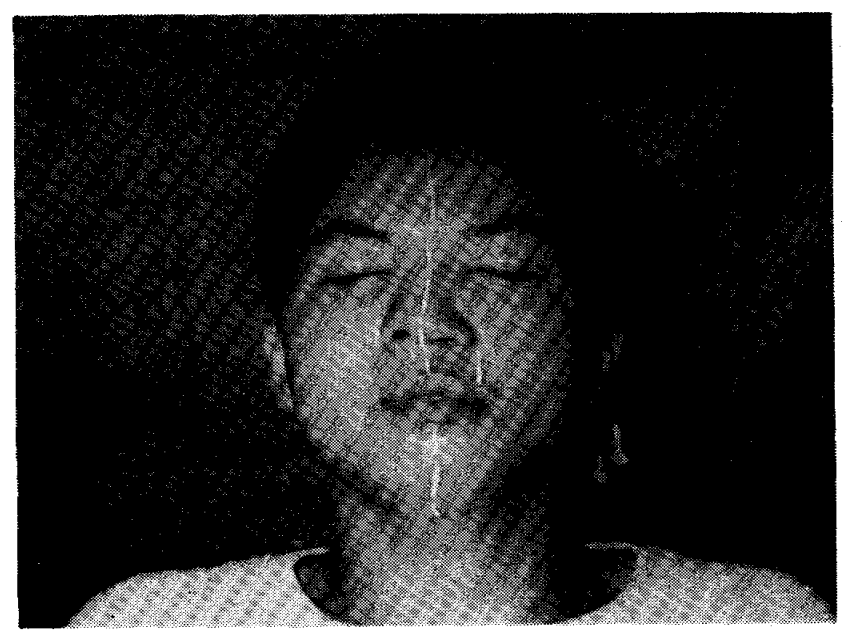

診断: 奇型治癒した左側上唇裂 (左側鼻翼変形).

処置ならびに経過：

左側鼻翼基底部の後退を示しているとてろから，左側 鼻翼基底部认腸骨の移植を行なった，右腸骨稜より，約 $1 \mathrm{~cm} \times 1 \mathrm{~cm} \times 4 \mathrm{~cm}$ の骨片を採取し，左側敬唇移行部に 横切開を加え，骨膜剥離子にて，鼻翼基 底部まで剥離 し，骨片移植を行なった。術後経過良好にて，21病日に 退院した。退院後 8 カ月を経過したが, 移植骨の吸収そ の他変化を認めない。

術後，側方頭部 X線規格写真による観察では，左右投 影值差 (実测值差) $2 \mathrm{~mm}$, 実長差 $0 \mathrm{~mm}$ で, 左侧鼻翼 
基底部の回復が，明らかに認められた（図 9，10，11参 照).

図 7

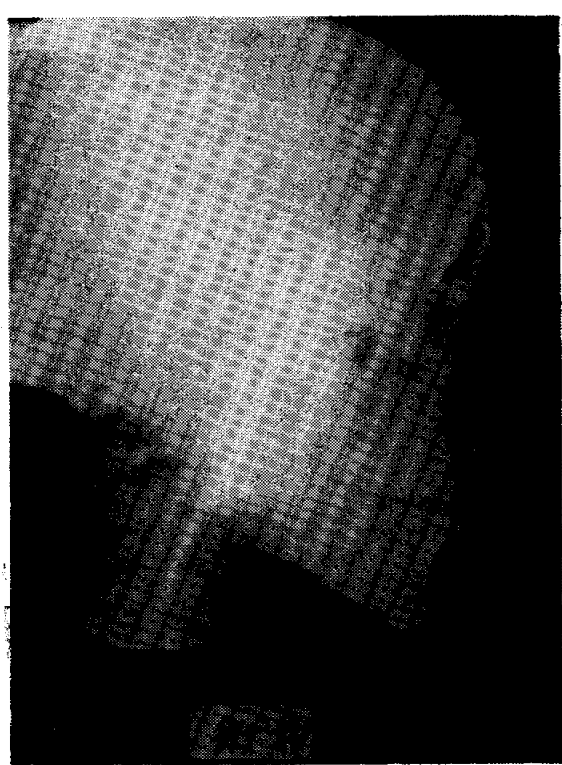

図8

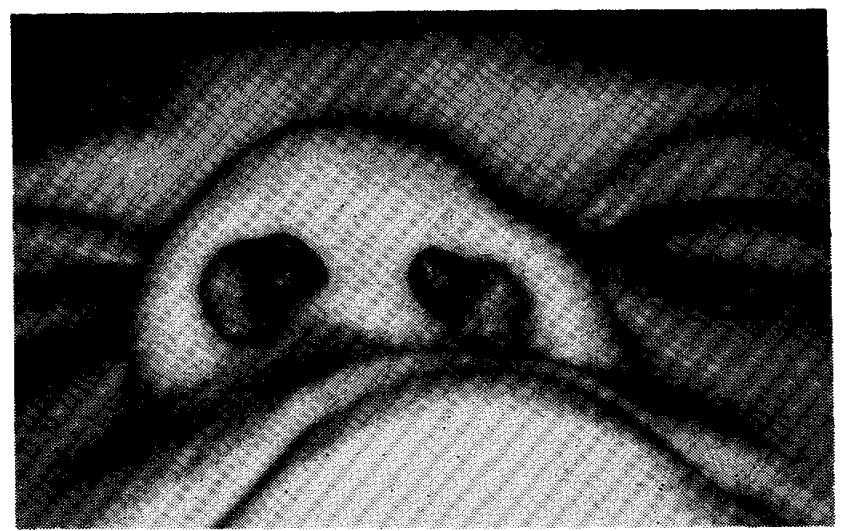

図 9

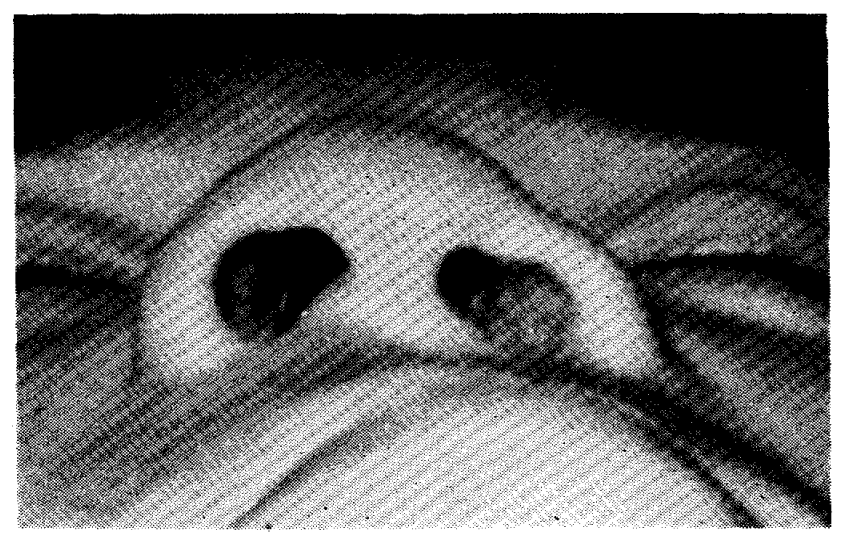

総括ならびに考案

頭部 X 線規格写真計測法は1931年, Broadbent 1 1) が, 頭部 X 線規格写真の撮影に成功して以来, 歯科矯正学の
図10

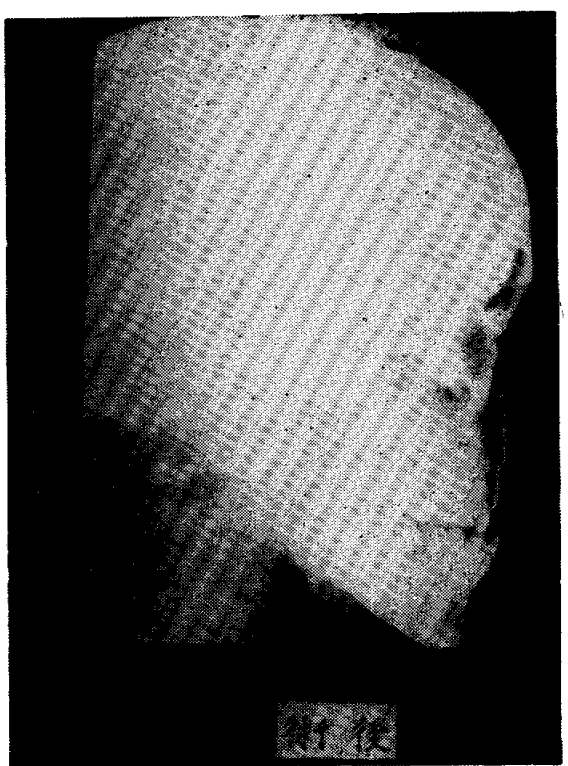

図11骨移植例の測定成績

\begin{tabular}{|c|c|c|c|}
\hline & & $\mid \begin{array}{l}\mathbf{X} \text { 線フィル公公で } \\
\text { 先右投影值差 }\end{array}$ & $\begin{array}{l}\text { 害長 差 } \\
\text { (換算值差) }\end{array}$ \\
\hline 術 & 前 & $6 \mathrm{~mm}$ & $4 \mathrm{~mm}$ \\
\hline 術 & 後 & $2 \mathrm{~mm}$ & $\mathrm{O} \mathrm{mm}$ \\
\hline
\end{tabular}

領域においてとりいれられ現在まで多数の業績がみられ る. とくに，頭蓋，顔面，顎骨，歯牙の相関的な症例分 析に利用され，診断，予後の判定に不可久のむのとなっ ている。

飯塚6)は，頭部 X線規格写真の応用について述へ，歯 科矯正学のみならず, 人類計测学, 遺伝学, 解剖学, 口 腔外科学, 耳鼻科領域, 外科領域, 内科領域, 顔面形成 外科領域一の応用が考えられるといっている，とりわ

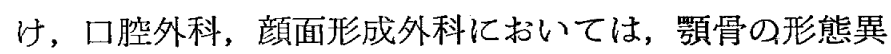
常, 病巣, 骨折片の偏位などにさいして, その位置, 程 度, 範囲の診查, 口蓋裂扔よび，下顎前突，開咬等にお ける外科的矯正における術前・後の比較検討, 経過観 察，顔面形成に批ける，診査，記録の資料としてなど， 多方面の応用が増大されると述べている.一方, 顎・顔 面・目空多科領域に打ける応用についてみると, 西鴆ら 2) は, 顎骨変形例，奇型例，顎骨腫瘍例に応用，高橋 ら3) は, 兔唇患者の側方に関する研究の一助として応用 している。 その他，渡辺ら4,5,9)の顎骨への骨移植に対す る応用, あるいは, 顔面非対称の観血的な処置例, 尾関 $ら^{12,13)}$, 舌の機能形態学的研究, 舌の位置検討などへ の応用の報告がみられる.

頭部 X線規格写真における, 分析法については, 種々 
なる計測法があり，そ机に関する業績は，多数みとめら れ，症例分析のための，基準值についても，多数の業績 がみとめられる7,8.10,11,15). しかし，側貌フィルムにお いて，左右が対称である 2 点は，フィルムに近い点と逗 い点では，当然一致しない，そこで，通常の計測では， その中点をとるようになっている，われわれが，おてな った方法は，その左右両側の計測点上，耳固定装置中央 部との距離を各々別に測定し，それを実長に換算し，そ の差を用いる力法，あるいは，各々の測定值差を利用す る力法であり，他に類をみないようである.

今回，われわれは，ほぼ正常な成人23例と唇・顎・ロ 蓋裂患者 9 例を測定した。唇・顎・蓋裂患者 8 例は， ほぼ正常之思われる成人23例之同㥞な成績をえたが，1 例は，明らかに差が認められた。年令, 性別については 検討を行なっていないので, 今後, 検討したいと思う.

頭部 X 線規格写真軟組織 貌をえるためには，尾 沢14) は，1）頭部 $\mathrm{X}$ 線規格写真之普通写真，2）撮影時に増 感紙使用フィルム之, 未使用のフィルムを同一カセット に入れ，現像後その 2 枚を重悋て用いる，3）X線装置 の管電圧を変えて用いる，4）被写体の軟組織に造影剂 を塗布する，5）補償フィルターを用いる方法，亡5つ の方法を述べている，われわれは，軟組織上の 2 点を測 定し, 同時に, 骨の状態観察のために, 尾沢の 4) の方 法を応用した。

造影剂については，硫酸バリウムを，モルヨドールに て練和して使用したが，軟組織に対して，さらに，易付 着性で，少量にて造影効果のあがるあのが望まれ，今 後，他の造影剂，金属粉等使用したいと考えている.

\section{むす び}

1）頭部 X線規格写真を応用した上顎測定法执よび, 測定成績について述べ，いささかの考察を行なった。

2) 側方頭部 X線規格写真を，骨移植片の厚さの決定 に利用し， I例ながら良好な結果をえた。

（本論文の要旨は，第13回日本形成外科学会総会，打 よで, 九州歯科学会昭和45年10月例会にて発表した）

\section{文献}

1. Broadbent, B. H. ; A new X-ray technique and its application to orthodontia: The angle orthodontist, I, 45, (1931).

2. 西嶋克巳, 森田知生, 吉津理; 顎口腔外科領域にお 汀頭部 X線規格 写真の臨 床的応用：日口外誌, 15, 3, 139-156, (1969).
3，高橋庄二郎，氏家英峰，渡辺甚一，重松知寛，皆葉 寿樹；頭部 X線規格写真（Franke 法）に上る鬼唇 患者の側貌に関する研究（抄）：形成外科，II（1 ), 74, (1968).

4. 渡辺義男，西鴄克巳，友沢 基，三宅 至，桜开 洋, 藤原弘亘, 横山里江; 顎骨骨移植におりるいわ

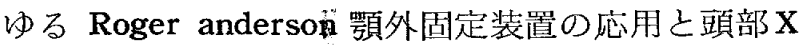
線規格写真による観繁：日可誌，11（3），232239, (1965).

5. 渡辺義男，西嶋克巳，小林敏郎，森田知生，植田寛 治；右側顎関節頭過形成（Hyperelasia）に上る顔 面非刘称の観血的治験例：日口外誌，10（2），211 -217 , (1964).

6. 飯塚哲夫；レントゲン・セファロメトリーの応用 とその現状：歯界展望，25（4），627-636， (1965).

7. 飯塚哲夫, 石川富士郎 ; 頭部 X 線規格写真に上る症 例分析法の基準值について一日本人成人男女正常 咬合群一：日矯雨誌, 16, 4-12, (1957).

8. 榎 恵：矯正診断代於付顔の分析法について：歯 界展望，11，297-306，(1954）.

9. 渡辺義男, 西嶋克已, 森田知生, 中谷昌慶；右上顎 中切歯の 180 度捻転せる唇罘口蓋裂患者に局所自家 細骨片移植を併用せる1治験例：日口外誌，9（1 ), 45-49, (1963).

10. 飯塚哲夫，石川富士郎；頭部 X線規格写真法におけ る計測点の設定について：日矯歯誌，16，66-75， (1957).

11，中後忠男，石沢命久，作田 守，岩崎重信，細見一 仁，河田昭茂；頭部 X 線規格正貌写真分析法に関す る正中線の決定について：日矯䒜誌，20（2），151 -157, (1961).

12. 尾関 哲, 中後忠男, 浅井保彦, 作田 守, 和田卓郎 ; X線法に上る舌の機能形態学的研究のためのマー カーについて：日矯歯誌，29（1），13-22, (1970).

13. 中後忠男, 尾関 哲, 浅井康彦; 頭部 $\mathbf{X}$ 線規格写真 法を応用した舌の位置の検討：日矯歯誌，29（1）, 23-35, (1970).

14. 尾沢光久; 頭部 X 線規格写真にお打る軟組織貌を得 るには：新歯潮，4（8)，281-282，(1970).

15. 高橋新次郎; 高橋・新編歯科矯正学, $65-73$, 永末 書店, (1964). 